\title{
SPECTRES OF MEMORY IN THE WORKS OF ISMAIL KADARE
}

\begin{abstract}
Jacques Derrida's spectre, as defined in Spectres of Marx (1993) is a figure that vacillates between presence and absence. It is something that both defines and disrupts the present by its absence and subsequent return. Indeed, it acts as a container of memory. What Martha and Bruce Lincoln define as secondary haunting is aimed at "broader forms of repair", such as creation of social consciousness about historical events and ensuring the "remembrance of atrocities" committed or traumas suffered. This type of secondary haunting is to be found in the works of Albanian nationalist writer Ismail Kadare. Not only does he make use of spectral figures like that of Sultan Murad I in Three Elegies for Kosovo (1998) but he also uses symbols such as the three-arched bridge in The Palace of Dreams (1981). Indeed, in The General of the Dead Army (1963), Kadare presses into action an entire army of dead soldiers. These spectres serve to keep alive the memories of atrocities and suffering, as well as those of ethnic origin among future generations. Additionally, the spectre of the Ottoman Empire, often as an allegory for Communism, also haunts the fictional world of Kadare's characters. Indeed, through these spectres Kadare is attempting to establish the European origins of his native Albania, while placing the burden of Balkan suffering on its Eastern oppressors.
\end{abstract}

Keywords: memory; hauntology; spectres; national identity; Ismail Kadare; Albania.

There is something dead in every living person, and vice versa.

(The Three-arched Bridge 82)

According to Pierre Nora, sites of memory exist "because there are no longer any milieux de memoire, settings in which memory is a real part of everyday experience." (1) The memory contained in these sites no longer influence life in the present. They have become containers to preserve the memory of certain people, events, occasions, etc. for future generations to

\footnotetext{
* Indian Institute of Engineering Science and Technology, Shibpur; India.
} 
venerate and learn from. However, power politics play a very significant role when it comes to choosing who and what is to be memorialised and for what purpose. Jacques Derrida writes in defining the term hauntology: “To haunt does not mean to be present." (202) Additionally, according to Abraham and Torok, "[w]hat haunts are not the dead, but the gaps left within us by the secrets of others." (171) Furthermore, as Avery Gordon writes, a haunting "is not a case of dead or missing persons sui generis, but of the ghost as a social figure." (25) That is to say, haunting does not need the presence of a spectral figure and when a haunting is represented or perceived it is not a case of a specific spectre patrolling a specific site but a memory of past events with the potential to disturb the social present.

"Derrida's spectre is a deconstructive figure hovering between life and death, presence and absence, and making established certainties vacillate." (Davis 376) A spectre is a question, neither positive nor negative, but demanding an answer. Indeed, "[ $t$ ]he being of the spectre cannot be identified with the appearance that gives it presence. It doesn't coincide with itself. But at the same time it is defined only by and through this appearing. Its presence hence becomes emblematic of its radical absence." (Loevlie 342) Therefore, a spectre is that which defines itself by its very absence; and in this absent presence it defines that which it haunts. A spectre disrupts the chronological nature of time. In a world obsessed with so-called 'rational thinking', chronology is an important metanarrative. Any disruption to it brings the entire narrative of the present into question.

According to Gordon, "[1]iterary fictions play an important role" in dealing with spectres and haunting. Literature "often teaches us, through imaginative design, what we need to know but cannot quite get access to." (25) It is this access that Albania's most well known writer, Ismail Kadare, has attempted to provide to his readers. Writing under the strict Stalinist dictatorship of Enver Hoxha, Kadare had to negotiate a difficult socio-political terrain. Kokobobo explains that the tenets of socialist realism insisted that "literature be fundamentally optimistic" and through this optimism it should be "reaffirming and propagating the communist status quo." ("The Decadent Muse" 147) It was impossible to be creative under such constraints especially since art was forbidden from imitating life. Indeed, anyone daring to circumvent or blatantly disregard the state-imposed requirements would be publicly humiliated and, in severe cases, imprisoned or executed. Kadare writes: "What we wrote was 
censored, but what was far worse than censorship was self-censorship. That was the real death of art." Despite the difficulties, whether by the use of allegory or by virtue of incompetence on the part of the censors and agents of surveillance, "Kadare himself managed to create sophisticated art, at times weaving different styles into his prose." ("The Decadent Muse" 149)

No obvious spectres could be present in his early work as such a thing would so obviously have gone against the tenets of socialist realism that not only would it have been impossible to publish, Kadare's own life may have been endangered. Kadare's spectres are not Derridean in the sense that they are rarely actual ghostly apparitions and that they do not seek specific vengeance like in Hamlet. However, they are revenants in that they "[begin] by coming back." (Italics in original, Derrida 11). They are absent presences that seek to haunt the entire Albanian population in order to remind them of their inner Albanianness. The function these spectres perform is along the lines of what Martha and Bruce Lincoln define as secondary haunting which is aimed at "broader forms of repair" such as creation of social consciousness about historical events and ensuring the "remembrance of atrocities" committed or traumas suffered. (Lincoln and Lincoln 201) In doing so, Kadare is, deliberately or not, emulating the dictatorship's tactics which were aimed at keeping the Albanians in a constant state of terror.

One of the most productive and efficient strategies to make Albanians believe that the war was "not over," or at least imminent, were the graphic representations recalling the war. This mission was performed through flooding the country with tombstones and headstones of the dead patriots, mainly from the Second World War. The extension of these graphic monsters inside the territory was immense, and the writings on these stony premises evoked the incessant presence of the heroes: these are and must be immortal, i.e. still alive and among the people. (Vishka and Çomo 1-2)

These became enforced sites of memory to maintain the feeling of fear rather than address the trauma or allow catharsis - a perversion in memorialisation. These were supplemented by thousands of empty pillboxes dotting the Albanian landscape to protect the nation against an imaginary invader. The Hoxha administration played on the Albanians' apprehension of another invasion - like the Ottomans or the Italians and Germans during the Second World War - and imposed a siege mentality on the nation that would throttle its progress right up to the fall of the Soviet Union in 1992. 
Under such circumstances, with the suppression of not only creative freedom but emotions, affects and memories along with it, some form of haunting becomes inevitable in the creations of the likes of Kadare. Most of his novels replicate the atmosphere of the classic ghost story. Dark, gloomy skies, menacing landscapes and characters with seemingly magical powers are common features. There is a constant air of mystery intertwined with misery. The Albanian landscape is often exoticised and its enigmatic qualities amplified. A number of hauntings take place in his novels. The spectres involved in these evoke Albania's Christian past and its inherent Europeanness to disturb the Hoxha administration's anti-West and anti-religious stance and indeed that of the supporters of Stalinist socialism. The spectres take on the forms of exhumed corpses, buildings, bridges, mythical figures and actual spirits. In each case, the spectre, irrespective of the form it takes, disrupts the narrative of both the fictional and the historical present. While there is significant scholarly literature on the works of Ismail Kadare, hauntological analysis is negligible. This paper will attempt to be a point of departure by applying not only the frameworks of hauntology but also of memory studies to show how Ismail Kadare is pursuing his agenda of establishing Albania as a European country by reimagining Albania's past and disrupting contemporary national narratives. This paper will examine three specific such presences in Kadare's novel, namely, the corpses of dead soldiers of the Italian army, the symbol of the three-arched bridge and the spirit of Sultan Murad I and how they disrupt both the fictional and the historical present.

The corpses appear in Kadare's first successful novel The General of the Dead Army (originally published in 1963). The novel fictionalises an Italian mission to repatriate the bodies of soldiers who had fallen in Albania during the Second World War. In the novel, the general in charge of this mission rather patriotically believes in the glory and honour of his nation's heroes. However, the extremely difficult and complicated process of finding these corpses that had been buried two decades ago, occasionally unceremoniously, and many of which remained missing disrupts his nationalistic optimism as he is forced to admit the absence of glory in the death of these soldiers.

The title of the novel itself indicates a return from the dead. The soldiers that had been buried since the war would be removed from their resting places, reorganised into battalions and returned to their homeland. But for the unnamed general, the army is very real. One drunken evening, he puts himself at the head 
of the army he is resurrecting and uses all his theoretical knowledge to win hypothetical battles against history's greatest generals such as Caesar and Napoleon. He then replays battles from the Second World War that were lost by the Axis powers and reverses the result with his "Nylon Army". (The General 12930) Not only are these egotistical delusions but they are also alternate histories created in an attempt to redefine the present perhaps to blot out or as a salve for painful memories of defeat. If the Axis powers had won those battles, if the Italian army had crushed the Albanian partisans entirely, the General would not have to be trudging through mud and dealing with inscrutable locals. He would have been able to stride the Albanian lands with pride looking down upon the natives as he had intended to do. (The General 9)

Under the aegis of Hoxha's strict literary policies of socialist realism, it was impossible to show ghosts of soldiers stalking the Albanian countryside to depict the continued effects of the Second World War even in the 1960s. Therefore, Kadare presses into action an entire army of corpses. They never appear in spectral form, yet, simply the presence of their corpses is disruptive of the General's perception of the war as well as of the narrative itself. The novel is based on an actual, historical repatriation that took place "some ten years after the WWII was over" (Vyshka and Çomo 2). This allows Kadare to retain some sense of realism even as he proceeds to disregard all other socialist literary tenets not least the ghost story-like setting but also a reluctant and distinctly pessimistic protagonist.

Each cemetery, indeed, each grave is a site of memory which is dismantled to be reconstructed back in Italy. However, it is not possible to surgically remove memories from their sites along with the memorials no matter how precise the process is. The atrocities committed by the Italian soldiers - destruction of villages, massacre of the people, rape - will continue to haunt the natives as long as the memory is alive. Every Albanian the General comes across recognises on him the emblems of a former enemy and is, as a result, angered, disgusted and hateful. They are aware of his mission and while their custom demands that the dead - even enemies - must be given proper burials, their national pride prevents them from embracing the General's presence among them. The deathly silence of the corpses is complemented by the voices of the dead soldiers which intrude upon the narrative flow in the form of diaries, testimonies of those who served with them and the memories of their relatives who come to meet the General before his departure to Albania. These memorial texts cause the General 
to rethink the patriotism of the Italian soldiers as well as his own. They disrupt the narrative and suddenly transport the reader two decades into the past, back to wartime, with all its horrors. Some testimonies reveal that some soldiers did not wish to be identified nor repatriated after their death. Indeed, many of these texts - written and oral - describe the ignominies accepted, often willingly, by the Italian soldiers who deserted their ranks and worked as mere labourers for Albanian farmers. This is diametrically opposite to the official national version as espoused by the General which painted all Italian soldiers who fought in the Second World War as martyrs who had "fallen for [their] country" and their deaths were not a matter of grief but of pride. (The General 35-6) At the same time, Italy's fascist legacy seems to have been confined to "a supposedly repudiated or overcome era in Italy's history." (Weitzman 285) Yet, the destruction wreaked on Albania by the Italian soldiers is seen by the General with a certain awe rather than the derision with which the natives see it. (The General 78)

Notably, none of the soldiers are named in the novel. Even in their own diaries their names are not to be found. Their identity is limited to their medallion (carried for that very purpose), their height, their dental records and, most of all, their burial place. In Imagined Communities, Benedict Anderson discusses the importance of the multiple tombs and cenotaphs for a revered Unknown Soldier to the national memory. This being is not a representative of the average soldier fighting on the battlefield but a manifestation of the national patriotic ideal. "Yet void as these tombs are of identifiable mortal remains or immortal souls, they are nonetheless saturated with ghostly national imaginings." (Italics in original, Anderson 9) The only soldier in the General's list who is given a name in the novel is also only allowed a rank and an initial: the enigmatic Colonel Z. Furthermore, he is on the list of those soldiers whose went missing in action and the location of whose graves are not known. When the General finally finds the remains of Colonel Z., they are thrown at his feet by an old and incensed Albanian woman who confesses to murdering the colonel as revenge for killing her husband and raping her daughter. On the way back to Tirana from the mountains, the General clumsily kicks the sack containing Colonel Z.'s remains into a river. This incident allows the enigma to remain around the notorious colonel and the truth about his war crimes and manner of death remains hidden from his family and the public at large. As a result, he will transform into a highly revered hero rather than a vile man who met a, perhaps deserved, unceremonious end. 
University of Bucharest Review $\approx$ Vol. XI/2021, no. 1 (new series)

Re-writing, Re-imagining the Past (III)

The three-arched bridge is the eponymous bridge of Kadare's novel The Three-arched Bridge (originally published in 1978). It is a fictional bridge over a river called the Ujana e Keqe which literally translates to "wicked waters". (Bridge 8) The novel takes elements from the Albanian version of the immurement myth or the master mason myth. This version tells the tale of the construction of Rozafa's castle wherein the spirit world demands that a mason's wife be immured into the foundations to allow the construction of the castle to be finished. Kadare replaces the castle with the three-arched bridge and it is a man who is immured in one of the piers. Crucially, Rozafa, the woman who was immured in the castle of the myth, had voluntarily accepted her faith once she had been made aware of it. In the novel, however, the man, who was suspected to have attempted to sabotage the construction, was possibly caught red-handed and murdered. This made the act of the immurement sacrifice an abomination rather than a pure ritual of faith. Indeed, since this man was playing the role of the spirits in trying to destroy the bridge, the fact that he himself was killed rather a sacrifice made by the bridge builders suggests man's dominance over the spirit world rather than an act of appeasement which the mythical sacrifice was. According to the narrator of the novel, an Albanian Christian monk, this bridge was built on the Via Egnatia along which Christian armies had gone on their Crusades against the Turks. (Bridge 26) In the novel, it is along this same road that Ottoman Turks now enter the Balkans with the view of taking over Europe. It is also on this bridge, the narrator tells us, that the first drops of Turkish blood on European soil are spilt. (Bridge 167)

This bridge becomes a site of memory of the Ottoman invasion and occupation of the Balkans as a well as a symbol of national and cultural identity for the Albanians within Kadare's fictional world. It reappears significantly in another novel by Kadare, The Palace of Dreams (originally published in 1981), where it represents the memory of the protagonist's Albanian origins. This novel is set in a fictional Ottoman capital that closely resembled Tirana of the 1970s and '80s but with horse-drawn carriages plying the streets lit by paraffin lamps. (Morgan 366) This, by itself, puts the present "out of joint" as Derrida, borrowing from Shakespeare, puts it. (1) The protagonist, Mark-Alem, belongs to a family of influential Ottomans who are of Albanian origin called the Quprilis. According to the family's origin story this bridge was built by one of their ancestors named Gjon. This is also the name of the monk in The Three-arched Bridge.

Therefore, the bridge is a site of memory for the Quprilis in particular. 
Indeed, they derive their patronymic from this bridge which is "a translation of the Albanian word Ura (qyprija or kuprija)." It is further mentioned in the family chronicle that "Gjon, followed an old custom and adopted the name of Ura, together with the stigma of murder attached to it." (The Palace 9) The family are haunted by the tragic immurement of the murdered man and carry the guilt in their very name. For Mark-Alem, centuries down the line, the bridge only exists in myth but it is imprinted in his memory and leads to an identity crisis. He yearns to go back to the simple culture and society that the bridge represents even as he becomes more and more powerful at the Ottoman centre. He is indifferent to the power that he has been bestowed with as he is unable to use it for the benefit of his original homeland which has remained at the margin.

The identity crisis comes to a head when Mark-Alem's favourite uncle, Kurt invites Albanian rhapsodists to perform at a family gathering. While listening to the epic songs, from which the Quprilis are vindictively removed because the Albanians see them as traitors (The Palace 63), Mark-Alem finds himself desiring to "discard...the Asian half of his first name and appear with...one used by the people of his native land: Gjon, Gjergj or Gjorg." (The Palace 152) It is at this same party that the Ottoman Sovereign's police raid the house and arrest Kurt for organising such a performance. They also kill the rhapsodist and, later in the novel, execute Kurt for what the state deemed to be an attempt to foment nationalistic feelings. (The Palace 166, 179) When migrants have assimilated into a new homeland with its own socio-cultural codes, any attempt to resurrect the codes of the former homeland will be seen as a threat. Thus, the very ethnicity of the Quprilis haunts them as they tread the thin line between assimilation and the maintenance of ethnic values. Furthermore, "[t]he three-arched bridge possibly derives from Christian [T]rinitarian symbolism" (Morgan 367) and links the Quprilis not only to Albania but to the Christian origins of Albania before the invasion of the Ottomans.

The spirit of Sultan Murad I is the first spectre as such that manifests in Kadare's work. This spirit appears in Three Elegies for Kosovo (originally published in 1998). As this novel was published in exile in France and after the fall of communism, Kadare was able to introduce a clearly mythological element as he was no longer constrained by the state-imposed tenets of socialist realism. Murad I was the first Ottoman ruler who invaded the Balkans in the $14^{\text {th }}$ century. He emerged victorious against the unified Balkan army under Prince Lazar of Serbia in the first Battle of Kosovo in 1389. Despite this victory he was assassinated and 
his son Bayezid, intent on bringing Islam to the West, took the Ottoman throne. ("The 'Curse' of Eastern Blood" 85) In a sub-chapter entitled "Supplement to the Report", it is revealed that "the monarch's body [was] taken to the Ottoman capital but that his blood and intestines [were] buried in the Christian soil of Kosovo." According to the narrator, this is significant because "the ancient Balkan people believed that everything linked with blood is eternal, imperishable, and guarded by fate." (Three Elegies 31)

It is almost as if the Turks, Ani Kokobobo writes, knowing the significance of blood to the Balkan people, sought to "impregnate the land of Kosovo with the Ottoman DNA." ("The 'Curse' of Eastern Blood" 87) This pregnancy is as perverted as the abominable immurement of the murdered man in The Threearched Bridge as the narrator himself describes it:

The wall indeed looked pregnant...But this was a perverse pregnancy...No baby emerged from it, on the contrary a human being was swallowed up...It was worse than perverse...It would have been perverse if, in contrast to a baby who emerges to the light, the man who entered the darkness were to shrink and be reduced to the size of an infant and then to nothing...But that was not to happen. This was a perversion of everything. It was perversity itself. (Bridge 105)

This was a pregnancy that would remain suspended in time; a perversion that would haunt the land and all those who were complicit for eternity. The guilt of that murder was to later haunt the Quprilis as they fell into a crisis of ethnic identity in The Palace of Dreams. The betrayal and absurd burial of the Sultan would haunt the entire Balkans for centuries. Three Elegies for Kosovo was published in the context of the wars in the Balkans after the fall of the Iron Curtain - especially the Serbo-Albanian conflict over Kosovo. In the novel, Kadare harks back to the time when the Balkans united against the Turks to protect Kosovo to illustrate the potential for unity that existed among the region's peoples. Yet, he also bemoans the fact that, despite the crushing defeat in the first Battle of Kosovo, Albanian and Serbian folk songs - allegorically representing the sentiments of the 1990s - continued to express hatred for each other.

Kadare locates the source of the Balkan wars of the 1990s in the bitter ancient rivalry the two nations shared over the plains of Kosovo. (Three Elegies 
51) The spirit of Murad I becomes the repository of the memory of the Balkans as it stands in the fields of Kosovo and recites the various conflicts that have taken place there. Despite his frustration with the constant rivalry between Albania and Serbia, Kadare takes recourse to implicating the Turks and their blood as the wellspring of all subsequent conflict. He makes the spirit speculate whether it was "[his] blood [that] is the origin of all this horror." (Three Elegies 87) Kadare, or, at least, the narrator of Three Elegies for Kosovo, asserts that although there were rivalries among the Balkan peoples they were able to unite when faced with a foreign enemy. However, this was before they were contaminated by Turkish blood, i.e. before the Turks assimilated into Balkan society and intermarriage took place between the two cultures. This, the narrator believes, has made it impossible for the Balkan peoples to achieve lasting peace in the region. Indeed, during the Balkan conflicts of the 1990s, when the Balkans were being considered barbaric and "not European" in much the same way as countries in Africa were orientalised (Rieff 24), Kadare, convinced of Albania's Europeanness, attempts to locate the barbarity in the blood of an ancient Asian enemy. Contrarily, the Italian soldiers, with their European blood, did not wish to be returned to their families. By himself wishing to be returned to Asia, Murad plays into Kadare's agenda of wanting to disinter all Ottoman influence from European Albania.

The spectres examined in this paper all have one agenda: ensure that past atrocities and failures in administration or, indeed, in ethnic loyalty are not forgotten in the present. These spectres disrupt narratives of the present at both the national and the individual level. The continued suffering of the people and the strict restrictions on creative expression of this suffering both under the Ottomans for five centuries and under the Socialists for five decades meant that there had been no space or time to come to terms with it. This has led to the construction of what Abraham and Torok define as an "intraphysic tomb", a crypt containing the memories of the object whose loss could not have been mourned and the trauma that prevented such mourning. (Abraham and Torok 130) Furthermore, "[t]he phantoms of folklore merely objectify a metaphor active in the unconscious: the burial of an unspeakable fact" within the object of mourning. (Abraham and Torok 172) This is replicated in the three-arched bridge containing the dark secrets of its victim's immurement - a man whose death could not be properly mourned as his death was neither a meaningful sacrifice nor was it sanctified with funereal rites. This stain of murder is transferred on to the Quprilis in the future as they struggle between their ethnic identity and 
desire for assimilation. The dead soldiers also could not have been mourned as their loved ones had never received their remains. Much the same applies to the spectre of Murad who was secretly assassinated and his blood injected into the Balkan land without the consent of its people who are yet to come to terms with it. Therefore, all of these spectres lead to the creation of intraphysic tombs or crypts. In order to reckon with the traumatic memories that are contained in them, the spectres interred in these crypts must be "decrypted." (LaCapra 379)

In the process of disinterring the corpses of the soldiers, the general is himself decrypting the spectres that would cause him to rethink his nationalistic worldview. Indeed, the narrative voice of the General says of the leader of the Albanian workmen who had fought as a partisan against the Italians: "He goes all over his country finding graves and digging memories of the war up out of them. He must certainly hate me." (The Palace 92) With regards to the spectre of Murad, by decrypting the spirit and giving it a voice, albeit laced with Eurocentrism, Kadare is once again putting the present out of joint. The spirit of Murad speaks not only of ancient conflicts but also of modern ones. "At first, the sultan rejoices seeing his enemies destroy one another, but eventually, he too tires of all the violence and begins to wonder if his presence may be the reason behind all the bloody confrontation." (The 'Curse' of Eastern Blood 88) In Derridian terms, the spirit of Murad I "comes back" not to ask for revenge but for redemption. The spirit haunts the land of Kosovo in a state of guilt and confusion demanding that his remains be disinterred from the land so that the Balkans can finally be peaceful and he can be at peace.

Through his work, Kadare's sole aim is to reconstruct Albanian national identity by disassociating his contemporary national consciousness from that of its former colonisers. The spectres that manifest in his texts and, through them, haunt the national consciousness preserve the memories of past and present suffering. They also serve to remind the Albanians of their ancient heritage and European ethnic identity. This is part of Kadare's agenda of returning Albania to a prelapsarian European, Christian Albania with its ancient cultures unstained by centuries of foreign occupation. Michael Rothberg reminds us that "sites of memory do not remember by themselves" (8). Unless memory and meaning are attached to them through individual or socio-cultural agency, these sites become impotent and are relegated to being mere statues and buildings. By not only invoking memories of Ottoman oppression but also creating sites of memory which, though fictional, are potent enough to cause disruptions in the 
contemporary Albanian national consciousness, Kadare seeks to reinvent, if not reconstruct, the Albanian identity in the post-Soviet era.

\section{Works Cited}

Anderson, Benedict. Imagined Communities. London and New York, Verso, 2006.

Davis, Colin. "Etat Present: Hauntology, Spectres and Phantoms." French Studies, vol. LIX, No. 3, 2005: 373-379.

Derrida, Jacques. Specters of Marx: The State of the Debt, the Work of Mourning and the New International. Translated by Peggy Kamuf, Routledge Classics, 2006.

Gordon, Avery F. Ghostly Matters: Haunting and the Sociological Imagination. University of Minnesota Press, 2008.

Kadare, Ismail. The General of the Dead Army. London, Vintage Random House, 2008.

---. The Three-Arched Bridge, London, Vintage Random House, 2013.

---. The Palace of Dreams, London, Vintage Random House, 2008.

---. Three Elegies for Kosovo, London, Vintage Random House, 2011.

Kokobobo, Ani. "The Decadent Muse in Ismail Kadare's 'The Albanian Writers' Union as Mirrored by a Woman.'" V zeleni drželi zeleni breg: Studies in Honor of Marc L. Greenberg, edited by Stephen M. Dickey and Mark Richard Lauersdorf, Bloomington, Indiana, Slavica Publishers, 2018: 143-56.

---. "The 'Curse' of Eastern Blood in Ismail Kadare's 'Elegy for Kosovo.'” Ulbandus Review, vol. 13, Columbia University Slavic Department, 2010: 79_ 93.

Lincoln, Martha, and Bruce Lincoln. "Toward a Critical Hauntology: Bare Afterlife and the Ghosts of Ba Chúc." Comparative Studies in Society and History, vol. 57, no. 1, 2015: 191-220.

Loevlie, Elisabeth M. "Faith in the Ghosts of Literature. Poetic Hauntology in Derrida, Blanchot and Morrison's Beloved." Religions, no. 4, 2013, pp. 336350. doi:10.3390/rel4030336

Morgan, Peter. "Between Albanian Identity and Imperial Politics: Ismail Kadare's 'The Palace of Dreams.'” The Modern Language Review, vol. 97, no. 2, Modern Humanities Research Association, 2002: 365-79.

Nora, Pierre. Realms of Memory: the Construction of the French Past. Translated by Arthur Goldhammer, edited by Lawrence Kritzman, vol. 1, Columbia University Press, 1996. 
Rieff, David. “Albania." Salmagundi, no. 116/117, Skidmore College, 1997: 19-31.

Rothberg, Michael. Noeuds de memoire: Multidirectional Memory in Postwar French and Francophone Culture. 2010, Stanford University Press.

Vyshka, Gentian, and Ariel Çomo. "Delusions of Immortality in a Post-War Society: The Albanian Case." Front. Psychiatry, vol. 10, 2019.

Weitzman, Erica. "Specters of Narrative: Ismail Kadare's 'The General of the Dead Army.'" Journal of Narrative Theory, vol. 41, no. 2, Department of English Language and Literature, Eastern Michigan University, 2011: 282309. 